\title{
Da autoprodução da razão (do absoluto), a chave do "devir" e a condição humana
}

\section{Of the self-generation of the reason (of the absolute), the key to "becoming" and human condition}

\author{
Luiz Carlos Mariano da Rosa ${ }^{1}$
}

\begin{abstract}
Resumo
O artigo em questão assinala o modo pelo qual a lógica acena com a emergência do Absoluto, segundo a leitura hegeliana, que, baseada no postulado que encerra uma equivalência entre o racional e o real, sublinha o movimento dialético que converge para a autoprodução da Razão, cujo processo traz o Estado como a sua realização através do Espírito objetivo, que implica uma relação antitética que envolve o Espírito subjetivo do homem e culmina na sua transposição em uma unidade substancial, a saber, o Espírito "em si" e "para si", o Absoluto como Espírito, puro saber de si da Ideia, perfazendo uma perspectiva que caracteriza a História como a encarnação do Espírito e atribui à liberdade uma condição que transcende o indivíduo e sua vida privada.
\end{abstract}

Palavras-chave: Hegel. Absoluto. Razão. Estado. Sociedade.

\begin{abstract}
The article points out the way in wich the logic nods with the emergence of the Absolute, the hegelian reading, wich, based on the postulate that closes an equivalence between the rational and the real stresses the dialectical movement that converges to the autoproduction of Reason process which brings the State as their goal achievement through the Spirit, which implies an antithetical relationship that involves the subjective Spirit of man, and culminates in its transposition into a substantial unity, namely, the Spirit "itself" and "for itself" the Absolute as Spirit, pure knowledge of the Idea itself, giving a perspective that characterizes the History as the incarnation of the Spirit and gives freedom a condition that transcends the individual and his private life.
\end{abstract}

Key words: Hegel. Absolute. Reason. State. Society.

\footnotetext{
${ }^{1}$ Escritor e poeta, pesquisador e ensaísta; Autor de O Todo Essencial, Universitária Editora, Lisboa, Portugal, e, entre outros, Quase Sagrado (em edição); Graduado em Filosofia pelo Centro Universitário Claretiano de Batatais (CEUCLAR/SP) e Pós-Graduando em Filosofia pela Universidade Gama Filho (UGF/RJ); Diretor-Fundador, Coordenador e Pesquisador do Espaço Politikón Zôon - Educação, Arte e Cultura (CNPJ nº 10.642.249/0001-54) e Empreendedor Sociocultural. E-mail: marianodarosaletras@terra. com.br
} 


\section{Aspectos Introdutórios}

A filosofia, ao dever ser ciência, não pode, para este efeito, como eu recordei noutro lugar [Fenomenologia do Espírito], pedir emprestado o seu método a uma ciência subordinada, como é a matemática, como tão pouco dar-se por satisfeita, com asseverações categóricas da intuição interior, nem servir-se de um raciocínio argüente fundado na reflexão exterior. Pelo contrário, só pode sê-lo a natureza do conteúdo, a qual se move no conhecer científico, sendo ao mesmo tempo esta reflexão mesma do conteúdo, que somente põe e produz a sua determinação mesma (HEGEL, 1993, p. 38).

Se a lógica ${ }^{2}$ na acepção de "ciência da ideia pura, isto é, da ideia do elemento abstrato do pensamento" (HEGEL, 1995, p. 65), se impõe, segundo a perspectiva hegeliana ${ }^{3}$, como uma análise que escapa ao horizonte que acena para os métodos de raciocínio ${ }^{4}$, convergindo para as fronteiras dos conceitos usados através do seu exercício, que remetem às categorias kantianas (a saber, Ser, Qualidade, Quantidade, Relação, etc.), a dissecação dessas noções básicas torna-se a primeira tarefa da filosofia, emergindo a Relação (Verhältnis) como a mais "difusa", tendo em vista que toda e qualquer ideia se mantém sob a perspectiva de "um grupo de relações", visto que a possibilidade envolvendo o pensamento, em função de alguma coisa, demanda uma construção de inter-relacionalidades diante de outra, operação que permite, enfim, a percepção de similaridades e diferenças, posto que a inexistência dos liames relacionais em questão não se põe senão para mostrá-la (a Ideia, no caso) como destituída de conteúdo, pois, vazia, enfim, o que implica uma equivalência entre o "Puro Ser e o Nada", cuja verdade, sobrepondo-se à indiferenciação que carregam e emergindo através da sua não identidade e sua diferença absoluta, implica um movimento de desaparecimento imediato de um no outro, a saber, o devir.

Transitar é a mesma coisa que devir; só que naqueles dois momentos, desde os quais se efetua o trânsito mútuo, são representados mais como repousando um fora do outro, e o transitar se representa como efetuando-se entre eles. Agora, onde e como se quer que se fale do ser ou do nada, tem que estar presente este terceiro; pois aqueles não subsistem por si, senão que existem somente no devir, neste terceiro (HEGEL, 1993, p. 121, grifo nosso).

Ao pensamento, ou às coisas - a toda ideia e a qualquer situação do mundo, em suma -, se impõe inevitavelmente o oposto, que posteriormente converge para a união que, envolvendo-os, possibilita a formação de um todo mais elevado e complexo, configurando a perspectivação que, dentre todas as Relações, é aquela que encerra o contraste, ou oposição, que emerge como universal, cujo "movimento dialético" guarda correspondência com uma ideia prenunciada por Empédocles e desenvolvida por Aristóteles através da noção da "média justa", à medida que defende que "o conhecimento dos opostos é uno", pois a evolução torna-se um desenvolvimento ininterrupto de oposições, que não se movimentam senão em função de uma fusão que, afinal, se inclina para a

\footnotetext{
2 “A lógica, se é realmente a disciplina da verdade, é ao mesmo tempo e indissoluvelmente ciência do Ser e do Pensamento. E seu conteúdo articulado só pode ser o Pensamento articulando-se enquanto pensamento do Ser e o Ser articulando-se enquanto é pensado." (CHÂTELET, 1995, p. 54).

3 “A Ciência da Lógica ocupa uma posição inaugural no sistema (hegeliano): a razão mostra em si as determinações abstractas [sic] da Ideia, cujas três primeiras dão o tom da dialéctica [sic]; o Ser - ser puro imediato, indeterminado -, a figura mais abstracta [sic] do pensamento, só é pensável na sua identidade com o Nada - não-ser imediato, igualmente indeterminado. A sua respectiva abstracção [sic] torna-os impensáveis sem a superação na sua síntese dialéctica [sic], primeiro conceito concreto, a categoria do devir" (BARAQUIN; LAFFITTE, 2004, p. 181, grifo do autor).

4 'Pensemos um momento no que significa 'raciocinar', no que quer dizer 'pensar'. Raciocinar, pensar, consiste em propor uma explicação, em excogitar um conceito, em formular mentalmente uma tese, uma afirmação; mas, a partir deste instante, começase a encontrar defeitos nessa afirmação, a pôr-lhe objeções, a opor-se a ela. Mediante o quê? Mediante outra afirmação igualmente racional, porém antitética da anterior, contraditória da anterior" (MORENTE, 1967, p. 268).

5 Legado do pensamento de Parmênides cuja relação se impõe à perspectiva de Hegel, que o incorpora, conforme sublinha a sua leitura: "A simples Ideia do ser puro foi expressa primeiramente pelos Eleatas e, especialmente, Parmênides como o absoluto e a única verdade; e nos fragmentos que nos chegaram dele, [se encontra expressa] com o puro entusiasmo do pensamento, que pela primeira vez se concebe em sua absoluta abstração: apenas o ser existe, e o nada não existe em absoluto" (HEGEL, 1993, p. 109, grifo nosso).
} 
reconciliação, tendo em vista que a verdade é uma unidade orgânica de partes contrárias ${ }^{6}$, consistindo o verdadeiro unicamente nessa diversidade que se reinstaura ou na reflexão em si mesmo no ser-outro, não perfazendo uma unidade original ou imediata enquanto tal, mas "é o vir-a-ser de si mesmo, o círculo que pressupõe seu fim como sua meta, que o tem como princípio, e que só é efetivo mediante sua atualização e seu fim" (HEGEL, 1992, p. 30).

Nessa perspectiva, pois, o "movimento dialético" não somente caracteriza o desenvolvimento e evolução do pensamento, tornando-se, inescapável ao âmbito desse horizonte, as coisas, posto que qualquer e toda situação se impõe através de uma contradição que converge, no processo que a detém, para as fronteiras de "uma unidade reconciliadora".

Se pensamento ${ }^{7}$ e ser $^{8}$ guardam relação, no tocante ao desenvolvimento que se lhes impõe, com o mesmo arcabouço de leis, lógica e metafísica ${ }^{9}$ emergem como uma coisa só, mantendo-se a mente, sob o horizonte em questão, à medida que se inclina sobre o processo dialético, como um instrumento indispensável que possibilita a sua percepção como tal, tanto quanto da unidade na diferença para cuja perspectiva acena, incorporando à filosofia o encargo de descobri-la (a saber, a unidade que, na diversidade, permanece em condição de latência), cabendo à ética a unificação do caráter e da conduta, como à política, aquele processo que envolve os indivíduos, em face da formação de um Estado, em uma contextualidade que, assinalando a absoluta racionalidade do projeto do mundo, demanda da religião ${ }^{10}$ o trabalho que implica o alcance do Absoluto, que inter-relaciona, afinal, todos os opostos, matéria e mente, sujeito e objeto, bem e mal.

Nessa perspectiva, pois, no qual o Absoluto, no homem, acede à consciência de si mesmo e se impõe como a Ideia Absoluta, a história emerge como um "movimento dialético", sob cujo horizonte os conflitos e as crises guardam sentido, escapando à interpretação que implica um "efeito ininteligível dos projetos de uma Providência exterior”, convergindo para as fronteiras que identificam os referidos fenômenos como a realização da Razão (cuja forma definitiva é o Estado moderno), conferindo o processo em questão à mudança a condição de referencialidade paradigmática da vida, à medida que defende a impermanência de qualquer e toda condição, tendo em vista que cada estágio traz uma contradição que só a "luta dos contrários" resolve. ${ }^{11}$

\footnotetext{
${ }^{6}$ Noção que guarda correspondência com a leitura de Schelling, que assinala, em suma, que "a verdade essencial do conflito de opostos não pode residir senão na unidade que sustenta esta oposição, fundamento sem o qual nenhum dos dois termos seria uma realidade" (BARAQUIN; LAFFITTE, 2004, p. 354).

7 “[...] Pensar, conhecer racionalmente, é compreender: a) que não se pode separar o pensamento como actividade [sic] do sujeito pensante (a razão como faculdade subjectiva [sic] de julgar, de 'discernir o verdadeiro do falso') e a realidade como objecto [sic] de pensamento (a razão como ordem inteligível das coisas); b) que o verdadeiro se reflecte [sic] naquilo que é. O pensamento enquanto 'conceito', a Razão, apreende-se como estando 'absolutamente junto de si próprio' na realidade, como simultaneamente subjectivo [sic] - proveniente do sujeito pensante - e objectivo [sic] proveniente da realidade pensável." (BARAQUIN; LAFFITTE, 2004, p. 179).

8 "Ser algo determinado significa em grego simplesmente ser e neste sentido ser é princípio do conhecimento: trata-se da medida de toda crítica consequente de conhecimento, uma vez que nenhum ato de pensamento pode ser executado sem pressupor que o pensado seja algo determinado. Pode-se dizer que nesta perspectiva o pensamento considerado ingênuo pela modernidade é mais radicalmente crítico do que o próprio pensamento da modernidade, pois a crítica já começa onde, de acordo com a modernidade, o pensamento ainda não interveio, ou seja, na fase puramente receptiva: o que não pode ser pensado, percebido, lembrado, representado como um algo de forma alguma pode ser conhecido em qualquer nível de conhecimento. Ser é assim um critério interno do próprio pensamento." (OLIVEIRA, 2007, p. 42).

9 Conclusão que se impõe à leitura hegeliana, que afirma que não é senão "a ciência lógica, que constitui a metafísica propriamente dita ou a filosofia especulativa" (HEGEL, 1993, p. 107).

10 "Na religião, o Espírito [...] separa o conteúdo espiritual da forma sensível; ele separa-se do sensível para tomar consciência de si como Absoluto no elemento da interioridade pura; mas a consciência religiosa dá ainda ao Absoluto uma forma exterior; pensa o Absoluto por meio da representação, como a singularidade de uma existência exterior, a de 'Deus"' (BARAQUIN; LAFFITTE, 2004, p. 180-181, grifo do autor).

11 “Certamente, a racionalidade global do processo escapa aos indivíduos, que realizam a necessidade sem dar conta disso: a Razão
} 


\section{Da Autoprodução da Razão (Do Absoluto ${ }^{12}$ )}

O que é racional é real e o que é real é racional.

Esta é a convicção de toda consciência livre de preconceitos e dela parte a filosofia tanto ao considerar o universo espiritual como o universo natural. Quando a reflexão, o sentimento e em geral a consciência subjetiva de qualquer modo consideram o presente como vão, o ultrapassam e querem saber mais, caem no vazio e, porque só no presente têm realidade, eles mesmos são esse vazio.

Quanto ao ponto de vista inverso, o daqueles para quem a Ideia só vale no sentido restrito de representação da opinião, a esses opõe a filosofia a visão mais verídica de que só a ideia, e nada mais, é real, e então do que se trata é de reconhecer na aparência do temporal e do transitório a substância que é imanente e o eterno que é presente.

Com efeito, o racional, que é sinônimo da Ideia, adquire, ao entrar com a sua realidade na existência exterior, uma riqueza infinita de formas, de aparências e de manifestações, envolve-se, como as sementes, num caroço onde a consciência primeiro se abriga mas que o conceito acaba por penetrar para surpreender a pulsação interna e senti-la bater debaixo da aparência exterior.

São infinitas as diversas situações que surgem nesta exterioridade durante a aparição da essência, mas não cumpre à filosofia regulá-las. [...].

A missão da filosofia está em conceber o que é, porque o que é é a razão [...] (HEGEL, 1997, p. 36-37, grifo do autor).

Ao objetivo da crítica kantiana, que guarda a pretensão de estruturalizar nas fronteiras da Razão o nó da articulação do conhecimento com o seu objeto, se impõe a descoberta do "eu penso" como o princípio da compreensão da relacionalidade da consciência com o ser, de cuja conclusão emerge, como obstáculo, o horizonte da "coisa em si”, que se não pode escapar ao ato de pensar (Denken), posto que inevitável, embora incognoscível, demandando a imposição de limites, pois, a interdição da Verdade Absoluta, do acesso ao Universal, em suma, que pressupõe a possibilidade do estabelecimento de uma comparatividade, no âmbito do conhecimento, envolvendo o finito e o Infinito.

Se a dificuldade que emerge através do legado em questão converge para a eliminação da "coisa em si”, que, segundo a leitura dos pós-kantianos (Fichte, Schelling e Hegel), se impõe como a possibilidade de constituir a filosofia como sistema da razão e como compreensão da realidade (Realität), a originalidade da perspectiva hegeliana consiste em manter a Realidade Absoluta, sob o horizonte que a identifica como substância (Substanz), que acena para os rastros do pensamento de Spinoza, considerando-a, também, como sujeito, pois detém em si mesma o princípio das suas determinações, sendo, para si própria, objeto, inteligibilidade, espírito, tendo em vista que o mundo não se permite deduzir ou construir a partir de uma unidade cuja concepção remeta à "indiferença absoluta".

O que há entre a razão como espírito consciente de si e a razão como realidade dada, o que separa a primeira da segunda e a impede de se realizar é o estar ela enleada na abstração sem que se liberte para atingir o conceito. Reconhecer a razão como rosa na cruz do sofrimento presente e contemplá-la com regozijo, eis a visão racional, medianeira e conciliadora com a realidade, $\mathrm{o}$ que procura a filosofia daqueles que sentiram alguma vez a necessidade interior de conceber e de conservar a liberdade subjetiva no que é substancial, de não a abandonar ao contingente e particular, de a situar no que é em si e para si. Isso é também o que constitui o sentido concreto do que já designamos, de maneira abstrata, como unidade da forma e do conteúdo. Com efeito, em sua mais concreta significação, a forma é a razão como conhecimento conceitual e o conteúdo é a razão como essência substancial da realidade moral e também natural (HEGEL, 1997, p. 38).

Nessa perspectiva, pois, o conhecimento da Realidade Absoluta, que emerge como substância e sujeito, não se torna acessível através da intuição

realiza-se por meio do seu contrário, o irracional; o universal pelo particular; o direito pela força; o bem pelo mal; a consciência pela inconsciência; a razão pelas paixões. [...] Mas, como se trata do desenvolvimento necessário do Espírito absoluto que não é nada sem o espírito dos homens, a grande questão da História não é senão a libertação humana; os seus efeitos perversos vão no sentido de a vontade humana poder desejar o melhor" (BARAQUIN; LAFFITTE, 2004, p. 182).

${ }^{12}$ Das Absolute, cuja noção, sob a leitura hegeliana, não guarda nenhuma correspondência com o Absoluto transcendente que o horizonte da Metafísica clássica encerra, caracterizando-se como a totalidade absolutamente inteligível que emerge a partir da sua necessidade interna e mantém parentesco com a Substância espinosista, expondo-se como tal ao termo do processo dialético do seu autopensar, constituindo-se simplesmente como a realidade total no movimento da sua automanifestação como Espírito (HEGEL, 1980, p. 41). 
(Anschauung), reivindicando, antes, à medida que as categorias, nas quais o espírito explicita o seu conteúdo, escapam aos meios que possibilitam a interpretação do real pelo entendimento (Verstand), a forma do conceito $^{13}$, cujo elemento guarda a possibilidade de conferir à verdade ${ }^{14}$ a estrutura do Sistema ou da Ciência, caracterizando-se como o termo-chave do pensamento de Hegel, que se impõe, propriamente, através do Absoluto ${ }^{15}$.

À possibilidade de aceder ao conhecimento de si, no tocante ao Absoluto $^{16}$, se impõe um sistema, na acepção de modo de desenvolvimento científico racional que, escapando às fronteiras da formalidade, detém uma necessidade interna, convergindo para a construção da totalidade do saber (Wissen) enquanto "Saber Absoluto", que não traz como fundamento senão o que por si próprio propõe à medida que dialoga com um horizonte de compreensibilidade que o encerra como autoprodução da Razão, à medida que, inexistindo a separação entre o sujeito (do conhecimento) e a substância, o verdadeiro (ou o Absoluto) se caracteriza como o sujeito de seu próprio desenvolvimento, como assinala a leitura hegeliana, que afirma que "[...], essencialmente, o verdadeiro é o sujeito: e como tal é somente o movimento dialético, esse caminhar que a si mesmo produz, que avança e que retorna a si." (HEGEL, 1992, p. 58).
À noção kantiana que converge para a perspectiva de que a consciência (ou sujeito) interfere ativamente na construção da realidade, Hegel impõe o horizonte que propõe o ser como processo, movimento, vir-aser (filosofia do devir), assinalando a sua constante transformação, que demanda, em suma, uma lógica que não se mantenha atrelada ao princípio de identidade (estático), mas que, trazendo como fundamento o princípio de contradição, seja capaz de se relacionar com a dinâmica do real, cuja constituição, escapando à leitura que o interpreta como um conjunto de "coisas acabadas", emerge como um complexo de processos no âmbito do qual a estabilidade caracteriza apenas a aparência.

\begin{abstract}
O botão desaparece no desabrochar da flor, e pode-se dizer que é refutado pela flor. Igualmente, a flor se explica por meio do fruto como um falso existir da planta, e o fruto surge em lugar da flor como verdade da planta. Essas formas não apenas se distinguem mas se repelem como incompatíveis entre si. Mas a sua natureza fluida as torna, ao mesmo tempo, momentos da unidade orgânica na qual não somente não entram em conflito, mas uma existe tão necessariamente quanto a outra; e é essa igual necessidade que unicamente constitui a vida do todo (HEGEL, 1992, p. 22).
\end{abstract}

Tese (identidade), antítese (contradição ou negação), síntese (positividade ou negação da negação). Eis as três etapas do movimento da dialética ${ }^{17}$, que, sob a perspectiva de que todas as coisas e ideias morrem, estabelece uma leitura

\footnotetext{
${ }^{13}$ Acenando com a superação da dualidade que envolve a essência e o fenômeno, a sua lógica emerge como o terceiro momento da lógica hegeliana, guardando distinção em relação ao "conceito universal" aristotélico como também à "categoria" kantiana, não perfazendo senão "a totalidade mediatizada (e, portanto, concreta) do ser e da essência e, como tal, é objeto da Razão (Vernunft) na sua oposição ao Entendimento (Verstand)" (HEGEL, 1980, p. 43). Conclusão: "Conceito e razão são sinônimos [sic]: o conceito (Begriff, apreensão conceptual) designa a verdadeira natureza do acto [sic] de pensar, que não consiste em opor uma ideia, uma representação mental, a um real, a um objecto [sic] exterior, a uma essência das coisas que seria o seu ser, separado do pensar" (BARAQUIN; LAFFITTE, 2004, p. 179, grifo do autor).

14 “A verdadeira figura da verdade está posta, assim, nessa cientificidade, ou, o que é o mesmo, afirma-se que somente no conceito a verdade encontra o elemento da sua existência" (HEGEL, 1980, p. 8).

15 “Ciência do Absoluto, a filosofia não tem qualquer objecto [sic] que lhe seja exterior: ela é seu próprio sujeito. Lógica e metafísica coincidem, sendo toda a realidade o fenômeno [sic] do espírito que se dá a compreender como o momento de um desenvolvimento necessário, o desenvolvimento que constitui o discurso do mundo na sua unidade" (BARAQUIN; LAFFITTE, 2004, p. 178).

16 “[...] O Absoluto é reflexão: o sistema especulativo é como uma imensa proposição cujo único sujeito se reflecte [sic] em predicados que possuem a marca da sua relação necessária com o sujeito. Todo o conhecimento de um objecto [sic] deve compreender que tem o pensamento como sujeito único, centro de todas as determinações" (BARAQUIN; LAFFITTE, 2004, p. 179, grifo do autor).

17 “A dialética é, pois, precisamente, a unidade negativa do movimento de dissolver-se e de produzir-se: 'ir ao abismo' significa se pôr no fundo das coisas. Trata-se da dissolução que o conceito efetua de si mediante a integração de seu movimento de particularização em uma nova posição" (ROSENFIELD, 1983, p. 53).
} 
que indica que a força da destrutividade se impõe, também, como aquela que impulsiona o processo histórico, tendo em vista que a morte carrega um potencial criador.

Com efeito, a Coisa mesma não se esgota em seu fim, mas em sua atualização; nem o resultado é o todo efetivo, mas sim o resultado junto com o seu vir-a-ser. O fim para si é o universal sem vida, como a tendência é o mero impulso ainda carente de sua efetividade; o resultado nu é o cadáver que deixou atrás de si a tendência. Igualmente, a diversidade é, antes, o limite da Coisa: está ali onde a Coisa deixa de ser; ou é o que a mesma não é (HEGEL, 1992, p. 23, grifo do autor).

Do grego dia, que expressa a ideia de "dualidade", "troca", e lektikós, "apto à palavra", "capaz de falar", traz a mesma raiz de logos, "palavra", "razão", guardando relação com o conceito de "diálogo" que, por sua vez, acena para o horizonte que encerra uma dualidade de razões, à medida que envolve mais de uma opinião - eis a etimologia de dialética ${ }^{18}$, cuja concepção converge para a conclusão de que a transição do ser para o não ser não acarreta aniquilamento, destruição ou morte pura e simples senão um movimento que conduz para as fronteiras de outra realidade, à medida que a contradição provoca a transformação do ser suprimido ${ }^{19}$.

Inter-relacionado à contraditoriedade dinâmica do real, a noção de totalidade, cuja leitura assinala a predominância do todo diante das partes que o constituem, traz subjacente a perspectiva de que as coisas estão em constante relação recíproca, escapando à compreensibilidade qualquer fenômeno da natureza ou do pensamento que porventura se incline à investigação de maneira isolada, à margem dos fenômenos circundantes, tendo em vista que participam de uma estruturalidade que se impõe pelo conjunto dialético ao qual pertencem.
Se o Absoluto se impõe como sujeito, a sua identidade não emerge senão através de uma dialética que, convergindo para a sua realização como tal, implica uma contradição que envolve uma forma imediata de subjetividade e a subtração desta no que tange à imediatidade, cuja ruptura, concernente à referida forma de subjetividade em face do imediato, perfazendo a liberdade, a interioridade, a transcendência infinita, se manifesta, inversamente, na identidade do Absoluto, uma vez que se lhe dispõe à medida que se reconcilia com a imediatidade, transformando-se em uma "imediatidade segunda", caracterizando-se o Absoluto, neste processo, como "essencialmente resultado", tendo em vista que encerra a condição de que é apenas no fim que é o que deve ser.

O verdadeiro é o todo. Mas o todo é somente a essência que se implementa através de seu desenvolvimento. Sobre o absoluto, deve-se dizer que é essencialmente resultado; que só no fim é o que é na verdade. Sua natureza consiste justo nisso: em ser algo efetivo, em ser sujeito ou vir-a-ser-de-simesmo. Embora pareça contraditório conceber o absoluto essencialmente como resultado, um pouco de reflexão basta para dissipar esse semblante de contradição. $\mathrm{O}$ começo, o princípio ou o absoluto - como de início se enuncia imediatamente - são apenas o universal. Se digo: "todos os animais", essas palavras não podem valer por uma zoologia. Do mesmo modo, as palavras "divino", "absoluto", "eterno" etc. não exprimem o que nelas se contém; - de fato, tais palavras só exprimem a intuição como algo imediato. A passagem - que é mais que uma palavra dessas - contém um tomar-se Outro que deve ser retomado, e é uma mediação; mesmo que seja apenas passagem a outra proposição. Mas o que horroriza é essa mediação: como se fazer uso dela fosse abandonar o conhecimento absoluto - a não ser para dizer que a mediação não é nada de absoluto e que não tem lugar no absoluto (HEGEL, 1992, p. 31).

Na perspectiva que implica a equivalência entre o racional e o real ${ }^{20}$, o sistema hegeliano, pois, explicando o movimento gerador da realidade,

18 “O motor da dialéctica [sic] é a negatividade, 'a seriedade, a dor, a paciência e a acção [sic] do negativo', negação do imediato e negação da negação que permite a afirmação de uma verdade superior, a elevação ao ponto de vista do Universal concreto, a Razão identificada com a totalidade do real" (BARAQUIN; LAFFITTE, 2004, p. 179, grifo do autor).

19 O verbo alemão Aufheben significa "suprimir", "negar", entendendo-se também na acepção de "conservar", tanto quanto de "elevar a um nível superior". "Hegel utiliza esse termo, jogando com sua ambiguidade, para designar, no movimento dialético, a passagem de um estado a outro. Todo novo estado nasce da negação do estado precedente: visa aboli-lo mas, de certa forma, conservá-lo. Assim, designa a ação de ultrapassar uma contradição" (JAPIASSÚ; MARCONDES, 2008, p. 21).

${ }^{20}$ No sentido que envolve efetividade (Wirklichkeit), que implica que "o mundo só está aí porque veio a ser em si mesmo o outro de si: o mundo é pelo movimento que o põe como unidade da diferença e da não-diferença. O que é, é o movimento de exposição 
desenvolve uma "dialética idealista"21, propondo que a racionalidade não se impõe apenas como o que é próprio ao sujeito humano, mas como a base e o motor do real, tornando-se o mundo, sob o horizonte em questão, a manifestação da Ideia.

\section{Da Chave do "Devir" 22}

A história do espírito é a sua ação, pois reside inteiramente no que faz e age; é fazer de si mesma, e isso na medida em que é espírito, o objeto da sua consciência, conceber-se a si mesma ao compreenderse. Este conceber-se a si é o seu ser e o seu princípio, mas, ao mesmo tempo, a plenitude de uma concepção é a sua alienação e transição para uma outra. Para se exprimir formalmente, o espírito que de novo concebe esta concepção de si e que regressa à alienação de si (que é o mesmo) constitui o grau na primeira concepção (HEGEL, 1997, p. 307-308).

Ao devir, Hegel impõe como princípio a Ideia $^{23}$ pura (tese), que para se desenvolver, gera um objeto oposto a si, a Natureza ${ }^{24}$ (antítese), que guarda o sentido de Ideia alienada (mundo destituído de consciência), de cujo confronto emerge uma síntese, o Espírito ${ }^{25}$ (pensamento e matéria, simultaneamente), como a Ideia que alcança consciência de si através da Natureza. Eis o movimento que se impõe à Razão, possibilitando-a transpor todos os graus, desde aquele que caracteriza a natureza inorgânica, da natureza viva, da vida humana individual até a vida social, emergindo estes dois últimos como a manifestação do "Espírito subjetivo" "26, ao qual se opõe a antítese do "Espírito objetivo"27, que converge para o sobrepujamento dessa relação antitética através do "Espírito absoluto", que encerra a superação das fronteiras que implicam a subjetividade e a objetividade e acena com a sua unidade substancial, perfazendo o Espírito "em si" e "para si", o Absoluto como Espírito (puro saber de si da Ideia), que traz a arte, a religião e a filosofia, como os seus três momentos (HEGEL, 1997, p. 307).

[...] Para Hegel, é o princípio absoluto, a divindade especulativa, a Ideia em uma palavra que sai de si e se aliena no mundo natural e na História. Após o que, há desalienação: através do mundo e da História, a Ideia, isto é, a divindade filosófica, se reencontra, se reconquista. O homem é o lugar deste vasto drama, o teatro deste cenário. No conhecimento, e por ele, o "homem" se procura; ele se descobre na razão. $\mathrm{Na}$ verdade, é a Ideia que se reconhece nele, desde a mais humilde sensação até a existência social eminente, a da moral, do direito, do Estado, enfim (DUVIGNAUD, 1974, p. 14-15).

Contrapondo-se à tradição jusnaturalista típica dos filósofos contratualistas, cujas teorias, construindo a hipótese do estado de natureza, convergem para a perspectiva que impõe à sociedade o caráter de uma composição de

da essência, é a autoapresentação do conceito.” (ROSENFIELD, 1983, p. 16, grifo do autor).

21 "A dialética superior do conceito consiste em produzir a determinação, não como um puro limite e um contrário, mas tirando dela, e concebendo-o, o conteúdo positivo e o resultado; só assim a dialética é desenvolvimento e progresso imanente. Tal dialética não é, portanto, a ação extrínseca de um intelecto subjetivo, mas sim a alma própria de um conteúdo de pensamento de onde organicamente crescem os ramos e os frutos. Enquanto objetivo, o pensamento apenas assiste ao desenvolvimento da ideia como atividade própria da sua razão e nenhum complemento lhe acrescenta da sua parte. Considerar algo racionalmente não é vir trazer ao objeto uma razão e com isso transformá-lo, mas sim considerar que o objeto é para si mesmo racional. Assim é o espírito em sua liberdade, a mais alta afirmação da razão consciente de si, que a si mesma se dá a realidade e se produz como mundo existente. A ciência apenas se limita a trazer à consciência este trabalho que é próprio da razão da coisa." (HEGEL, 1997, p. 33-34).

22 "Em Hegel, o devir constitui a síntese dialética do ser e do não ser, pois tudo o que existe é contraditório, estando, por isso mesmo, sujeito a desaparecer (o que constitui um elemento constante de renovação). A filosofia tem que "pensar a vida", diz Hegel. Quer dizer, pensar a história, o devir dos homens e das sociedades. Assim, a historicidade entra como a dimensão fundamental do real e o devir se torna a verdade mesma do Ser" (JAPIASSÚ; MARCONDES, 2008, p. 72).

23 "Forma lógica pura em si mesma do conceito pensado como realizado, ou o conceito no elemento abstracto [sic] do pensamento, a verdade no seu nível mais formal" (BARAQUIN; LAFFITTE, 2004, p. 180, grifo do autor).

24 “A Ideia dando a si própria a existência de um Ser-aí, 'a Ideia na forma da alteridade', o conceito (ou razão) alienando-se na matéria, a fim de, perdendo-se nela, reassumir-se nela para si” (BARAQUIN; LAFFITTE, 2004, p. 180, grifos do autor).

25 “'A Ideia no elemento do espírito humano', a Ideia chegada à existência em si e para si ou a Natureza aparecendo a si própria (para si) como Ideia” (BARAQUIN; LAFFITTE, 2004, p. 180, grifos do autor).

26 "Vida interior individual, cuja alma sensível a dialéctica [sic] eleva à liberdade e à vontade" (BARAQUIN; LAFFITTE, 2004, p. 180).

27 "Realização da vontade livre na História, no mundo das instituições jurídicas, onde as leis garantem a passagem do Universal ao individual, encontrando a sua forma consumada no Estado" (BARAQUIN; LAFFITTE, 2004, p. 180). 
indivíduos isolados, que se reúnem através de um pacto a fim de estabelecer artificialmente o Estado, garantindo tanto a liberdade individual como a propriedade privada, Hegel não define o homem senão como sendo sempre um indivíduo social, negando a sua anterioridade em relação ao Estado que, constituindo-o, segundo tal leitura, fundamenta a sociedade, sintetizando, através da realidade coletiva, a totalidade dos interesses contraditórios interindividuais.

Se o Estado é o espírito objetivo, então, só como membro é que o indivíduo tem objetividade, verdade e moralidade. A associação como tal é o verdadeiro conteúdo e o verdadeiro fim, e o destino dos indivíduos está em participarem numa vida coletiva; quaisquer outras satisfações, atividades e modalidades de comportamento têm o seu ponto de partida e o seu resultado neste ato substancial e universal. Considerada abstratamente, a racionalidade consiste essencialmente na íntima unidade do universal e do indivíduo e, quanto ao conteúdo, no caso concreto de que aqui se trata, na unidade entre a liberdade objetiva, isto é, entre a vontade substancial e a liberdade objetiva como consciência individual, e a vontade que procura realizar os seus fins particulares; quanto à forma, constitui ela, por conseguinte, um comportamento que se determina segundo as leis e os princípios pensados, isto é, universais. Esta ideia é o ser universal e necessário em si e para si do espírito (HEGEL, 1997, p. 217-218).

Síntese, eis o horizonte para o qual acena a família, que emerge através dos interesses contraditórios dos seus membros, tanto quanto a sociedade civil ${ }^{28}$, à medida que se impõe sobrepujando as divergências interfamiliares, representando o Estado, "que é o fim e a realidade em ato da substância universal e da vida pública nela consagrada" (HEGEL, 1997, p. 149), a unidade final, tendo em vista que encerra a superação da relação de incompatibilidade existente entre as esferas privada e pública. "O estado não é totalitário, mas é ele - por oposição ao jogo da competição econômica - que assegura para Hegel universalidade às ações humanas." (MERQUIOR, 1969, p. 22).
É o Estado, a realidade em ato da liberdade concreta. Ora, a liberdade concreta consiste em a individualidade pessoal, com os seus particulares, de tal modo possuir o seu pleno desenvolvimento e o reconhecimento dos seus direitos para si (nos sistemas da família e da sociedade civil) que, em parte, se integram por si mesmos no interesse universal e, em parte, consciente e voluntariamente o reconhecem como seu particular espírito substancial e para ele agem como seu último fim. Daí provém que nem o universal tem valor e é realizado sem o interesse, a consciência e a vontade particulares, nem os indivíduos vivem como pessoas privadas unicamente orientadas pelo seu interesse e sem relação com a vontade universal; deste fim são conscientes em sua atividade individual (HEGEL, 1997, p. 225-226).

Se a família ${ }^{29}$ se impõe primeiramente, tornando-se a encarnação da vontade, à medida que a subjetividade institui fronteiras para deter o desejo, enquanto se propõe obrigações, em nome de um direito de pertinência que não acena senão para o horizonte do "reconhecimento", guardando liames que envolvem os "sentimentos naturais", o seu contéudo apela à forma, não havendo outro, posto que a sua capacidade de assegurar-se como tal implica fatores contingentes, a saber, aqueles que envolvem do estabelecimento do vínculo do amor à constituição do patrimônio, tendo em vista que:

[...] A família realiza-se em três aspectos:

a) $\mathrm{Na}$ forma do seu conceito imediato, como casamento;

b) Na existência exterior: propriedade, bens de família e cuidados correspondentes;

c) Na educação dos filhos e na dissolução da família (HEGEL, 1997, p. 150).

Nessa perspectiva, pois, "a" família, de fato, "não existe", demandando a sua concepção a pluralidade ("as"), tornando-se inescapável uma leitura que a mantenha (digo, a concepção, mais do que a família) sob o horizonte de uma organização que se impõe à luta pela subsistência, à medida que a sua existência remete à Sociedade civil, visto que: "De

\footnotetext{
28 "Sociedade civil, associação de membros, que são indivíduos independentes, numa universalidade formal, por meio das carências, por meio da constituição jurídica como instrumento de segurança da pessoa e da propriedade e por meio de uma regulamentação exterior para satisfazer as exigências particulares e coletivas." (HEGEL, 1997, p. 149).

29 "Como substancialidade imediata do espírito, a família determina-se pela sensibilidade de que é una, pelo amor, de tal modo que a disposição de espírito correspondente é a consciência em si e para si e de nela existir como membro, não como pessoa para si." (HEGEL, 1997, p. 149).
} 
um modo natural e, essencialmente, de acordo com o princípio da personalidade, divide-se a família numa multiplicidade de famílias que, em geral, se comportam como pessoas concretas independentes e têm, por conseguinte, uma relação extrínseca entre si." (HEGEL, 1997, p. 166).

Sociedade civil. A propósito:

\begin{abstract}
A pessoa concreta que é para si mesma um fim particular como conjunto de carências e como conjunção de necessidade natural e de vontade arbitrária constitui o primeiro princípio da sociedade civil. Mas a pessoa particular está, por essência, em relação com a análoga particularidade de outrem, de tal modo que cada uma se afirma e satisfaz por meio da outra e é ao mesmo tempo obrigada a passar pela forma da universalidade, que é o outro princípio. Na sua realização, assim determinada pela universalidade, o fim egoísta é a base de um sistema de dependências recíprocas no qual a subsistência, o bem-estar e a existência jurídica do indivíduo estão ligados à subsistência, ao bem-estar e à existência de todos, em todos assentam e só são reais e estão assegurados nessa ligação. Pode começar por chamarse tal sistema o Estado extrínseco, o Estado da carência e do intelecto (HEGEL, 1997, p. 167-168).
\end{abstract}

Se a sociedade civil se impõe, no que tange ao universal, como uma realização mediata, a harmonia não emerge senão através de uma espécie de estratagema, segundo a leitura em questão, à medida que cada qual, trabalhando para si - ou acreditando fazê-lo -, confere aos outros de fato a oportunidade de trabalhar, perfazendo uma conjuntura que assinala, em suma, uma distinção envolvendo o que é realizado (o universal) e o que, em cada caso (o particular), é desejado, convergindo para a conclusão que demanda outra forma de Estado que se sobreponha ao "Estado do entendimento e da necessidade", ao mundo da particularidade (esfera econômica), enfim, no âmbito do qual, a liberdade, sob a égide do interesse pessoal, não se circunscreve senão ao horizonte do empírico, guardando, contudo, a possibilidade de preparar o homem para a cidadania, tanto quanto, consequentemente, "para querer o universal como tal” (HYPPOLITE, 1971, p. 103).
Como cidadãos deste Estado, os indivíduos são pessoas privadas que têm como fim o seu próprio interesse: como este só é obtido através do universal, que assim aparece como um meio, tal fim só poderá ser atingido quando os indivíduos determinarem o seu saber, a sua vontade e a sua ação de acordo com um modo universal e se transformarem em anéis da cadeia que constitui o conjunto. O interesse da ideia, que não está explícita na consciência dos membros da sociedade civil enquanto tais é aqui o processo que eleva a sua individualidade natural à liberdade formal e à universalidade formal do saber e da vontade, por exigência natural e também por arbitrariedade das carências, o que dá uma cultura à subjetividade particular (HEGEL, 1997, p. 170-171).

Consistindo na própria vida dos povos, em suma, à História, no tocante a sua realização, se impõe a ação dos indivíduos, jamais escapando tal processo à governabilidade da Razão, emergindo "os grandes homens" como "indivíduos naturais", cujos fins particulares, implicando o arrebatamento das paixões, a busca de glória e fortuna - na perseguição dos quais se detêm ${ }^{30}$-, não convergem senão para a realização do destino.

Não se pense, porém, que a história universal é o
simples juízo da força, quer dizer, da necessidade
abstrata e irracional de um destino cego; antes,
sendo em si e para si razão, e como o seu ser para
si é no espírito um saber, a história é, de acordo
com o conceito da sua liberdade, o desenvolvimento
necessário dos momentos da razão, da consciência
de si e da liberdade do espírito, a interpretação e a
realização do espírito universal (HEGEL, 1997, p.
307).

Se a sensatez caracteriza o Homem, que, nessa perspectiva, não tem outra aspiração senão a Razão e a liberdade, as consequências que implicam o processo que envolve a sua busca, convergindo para a caotização, em suma, se impõem como a chave do devir da Humanidade, que, acenando para a possibilidade de uma história (historia rerum gestarum), emerge, sob a acepção de um princípio imanente (sem o qual o passado, o presente e o futuro perdem a inteligibilidade), como a própria liberdade, à medida que o devir em questão, que se descobre, progressivamente, como Razão, não é senão o da liberdade ${ }^{31}$. Conclusão:

\footnotetext{
${ }^{30}$ Tendo em vista que neles "a Natureza (a Ideia feita Natureza) produz como um instinto a intuição daquilo que o Espírito exige e que coincide com a própria espontaneidade, com as suas paixões e caracteres.” (BARAQUIN; LAFFITTE, 2004, p. 182).

31 "Segundo Hegel, história e razão se interpretam uma pela outra. O absoluto, sem as formas que assume necessariamente na
} 
O elemento de existência do espírito universal - que é intuição e imagem na arte, sentimento e representação na religião, pensamento puro e livre na filosofia - é, na história universal, a realidade espiritual em ato, em toda a sua acepção: interioridade e exterioridade. Constitui a história um tribunal porque, na sua universalidade em si e para si, o particular, os penates, a sociedade civil e o espírito dos povos em sua irisada realidade apenas são como algo da natureza da ideia separada; neste elemento, o movimento do espírito consiste em tornar isso evidente (HEGEL, 1997, p. 307).

À perspectiva em questão, que torna relevante o horizonte sob o qual a liberdade se esconde, se impõe o sentido que a leitura hegeliana confere à Sociedade civil, que se torna o âmbito no qual à possibilidade de exercício da liberdade real se sobrepõem os atalhos estéreis do interesse, à medida que converge para as fronteiras de um sistema instável caracterizado pela satisfação das necessidades egoístas, tendo em vista que a verdade do homem não se detém no econômico, cuja esfera não encerra senão uma liberdade que não guarda capacidade de assumir a condição que se lhe cabe, e para a qual tende, a saber, aquela que implica a razão, tornando-se competência do Estado (que existe), espaço por excelência dos interesses públicos e universais, a realização da "liberdade efetiva".

É o Estado a realidade em ato da liberdade concreta. Ora, a liberdade concreta consiste em a individualidade pessoal, com os seus particulares, de tal modo possuir o seu pleno desenvolvimento e o reconhecimento dos seus direitos para si (nos sistemas da família e da sociedade civil) que, em parte, se integram por si mesmos no interesse universal e, em parte, consciente e voluntariamente o reconhecem como seu particular espírito substancial e para ele agem como seu último fim (HEGEL, 1997, p. 225).

Se, sob a forma do acontecimento, a História se impõe como a encarnação do Espírito, que emerge através da realidade natural imediata, as etapas do processo evolutivo guardam relação com os princípios propostos por esta última, inter-relacionando uma pluralidade de termos exteriores, cada povo detendo um, à medida que se trata da "existência geográfica e antropológica do Espírito", posto que o desenvolvimento particular de um povo histórico corresponde à evolução de seu princípio, desde o estado da infância até o alcance da consciência de si objetivamente moral, acenando para um período de decadência, em virtude da manifestação de um princípio superior, a negação daquele, leitura que assinala que as determinações geográficas se impõem às disposições históricas, delineando o destino dos povos (HEGEL, 1997, p. 309).

Se a História escapa à concepção que a encerra como uma força cega, convergindo para as fronteiras que assinalam o movimento evolutivo sob o horizonte da consciência da liberdade, "o devir-Espírito da humanidade" que se inclina para a libertação do "ser-aí" natural, possibilitando-o encarnar uma Verdade em ato, cuja realização não emerge senão na vida concreta de cada indivíduo, o pensamento hegeliano, nessa perspectiva, justifica a guerra $^{32}$, por exemplo, tendo em vista que o seu fim se impõe, à medida que tende a perder o seu caráter de violência irracional (HEGEL, 1997, p. 305-306).

\section{Da Condição Humana (Da Dialética)}

O senhor se relaciona mediatamente com o escravo por meio do ser independente, pois, justamente ali, o escravo está retido; essa é sua cadeia, da qual não podia abstrair-se na luta, e por isso se mostrou dependente, por ter sua independência na coisidade. O senhor, porém, é a potência sobre esse ser, pois mostrou na luta que tal ser só vale para ele como um negativo. O senhor é a potência que está por cima desse ser; ora, esse ser é a potência que está sobre o Outro; logo, o senhor tem esse Outro por baixo de si: é este o silogismo [da dominação]. O senhor também

história, seria a 'solidão sem vida', é a história é aquilo com que nos devemos reconciliar. A liberdade é esta própria reconciliação. A liberdade hegeliana, insistimos, transcende o indivíduo e sua vida privada; é uma reconciliação do homem com o seu destino, e a expressão desse destino é a história.” (HYPPOLITE, 1971, p. 108).

32 “A guerra é uma negação da negação, a vida material de um povo, de vez que a sua particularidade positiva constitui-se precisamente de limitações ou negações. Na guerra, essas negações são por sua vez negadas, e a mais alta liberdade, a que consiste em não ser escravo da vida, se manifesta" (HYPPOLITE, 1971, p. 80). 
se relaciona mediatamente, por meio do escravo com a coisa; o escravo, enquanto consciência-de-si em geral, se relaciona também negativamente com a coisa, e a suprassume. Porém, ao mesmo tempo, a coisa é independente para ele, que não pode, portanto, através do seu negar, acabar com ela até a aniquilação; ou seja, o escravo somente a trabalha. Ao contrário, para o senhor, através dessa mediação, a relação imediata vem-a-ser como a pura negação da coisa, ou como gozo - o qual the consegue o que o desejo não conseguia: acabar com a coisa, e aquietar-se no gozo. $\mathrm{O}$ desejo não o conseguia por causa da independência da coisa; mas o senhor introduziu o escravo entre ele e a coisa, e assim se conclui somente com a dependência da coisa, e puramente a goza; enquanto o lado da independência deixa-o ao escravo, que a trabalha (HEGEL, 1992, p. 130-131).

À leitura hegeliana da função do trabalho ${ }^{33}$, se impõe a questão que, nessa perspectiva, envolve a determinação que não se detém nas fronteiras que convergem para descobrir "se o homem é livre, mas em que condições o é", tendo em vista que a liberdade escapa ao horizonte que implica um ideal, caracterizando-se, pois, como um fato, demandando a definição das modalidades efetivas "nas e pelas quais" o desejo humano, assumindose como vontade, alcança realização, à medida que constrói um arcabouço de ações que concorrem para possibilitar uma relação que não se inclina senão sobre o seu objetivo, não emergindo como menos do que se tornar efetivamente vontade livre.

"Tal realização consiste, em seguida, por meio da abolição daquela oposição, negação da negação, em dar-se, como negatividade que a si se aplica, a determinação de vontade na sua existência empírica de tal sorte que ela seja vontade livre não apenas em si mas para si." (HEGEL, 1997, p. 94).

Se Hobbes, um dos teóricos do "estado de natureza", que guarda relacionalidade com a hipótese de uma condicionalidade primitiva, anterior ao processo de sociabilidade, caracterizada, pois, por uma vivencialidade fundamentalizada pela liberdade, à medida que o homem guarda possibilidade ilimitada de usufruir as coisas e realizar os seus desejos, interpreta a situação em questão (que envolve a "vontade livre") como "reino do arbitrário", o seu único erro consiste em "abstraí-lo", posto que o isola "como fato originariamente irredutível", comprometendo toda a sua demonstração, tendo em vista que, como um ser que deseja, a necessidade se impõe sob um horizonte que esconde que mais do que o seu corpo mesmo, o que está em seu poder não é senão o "direito" de querer (Wollen) tudo o que possibilita a garantia da sua sobrevivência, não havendo fronteiras outras para a sua liberdade que escapem à sua potência, à medida que a posse de um corpo confere legitimidade acerca da sua utilização e do usufruto dos bens necessários para a sua satisfação, não se constituindo a liberdade em si senão no modo do ter (da posse), que, caracterizando-se como precária, apenas alcança condição de propriedade, se for garantida.

Do ponto de vista da carência, e caso esta seja colocada em primeiro plano, ter uma propriedade aparece como um meio. Mas é noutro ponto de vista que reside a verdadeira situação, o da liberdade que na propriedade tem a sua primeira existência, o seu fim essencial para si (HEGEL, 1997, p. 47).

Se o pensamento de Rousseau, à medida que acena para a leitura de que outro direito não há senão o que implica o desejo, converge para o equívoco, se impõe como certo, ao assinalar que a sua satisfação duradoura remete a um direito que é diferente do "direito de fato", guardando relação com uma ordem que somente emerge como tal enquanto transcendente ao que organiza, tendo em vista que a posse, cujas modalidades são tanto a ocupação quanto a transformação (conforme defende a perspectiva lockeana), apenas se constitui em propriedade por intermédio da instituição do contrato.

Como ser determinado, a existência é essencialmente ser para algo que é outro. Deste ponto de vista de

33 "Foi Hegel quem formulou a primeira teoria filosófica do Trabalho, utilizando os resultados a que chegara Adam Smith na Economia Política. Já em Lições de Iena (1803-04), Hegel considerava o Trabalho como "mediação entre o homem e seu mundo"; isso porque, diferentemente dos animais, o homem não consome de imediato o produto natural, mas elabora de maneiras diferentes e para os fins mais diversos a matéria fornecida pela natureza, conferindo-lhe assim valor e conformidade com o fim a que se destina (Fil. do Dir., § 196)" (ABBAGNANO, 2007, p. 965, grifo do autor). 
existência como coisa exterior, a propriedade é para outras exterioridades e liga-se à necessidade natural e à contingência que disso resultam. Mas, como existência da vontade, essa sua existência para outrem é existência para a vontade de outrem. Nesta relação de vontade, a vontade constitui o terreno próprio e verdadeiro onde a liberdade tem uma existência. É esta mediação que constitui o domínio do contrato, esta mediação que a propriedade estabelece, não só de uma coisa com a minha vontade subjetiva mas também com outra vontade, havendo, portanto, uma vontade comum de posse (HEGEL, 1997, p. 69-70).

Se a existência da propriedade demanda o seu reconhecimento, o contrato se impõe como a verdade (essência) da liberdade que emerge em si, cuja realização, nesse sentido, corresponde

[...] apenas se o ter no qual ela tem sua efetividade encontra uma legitimação num direito: o direito privado ('privado', no momento, pela verdade que lhe dará, segundo Hegel, o universal concreto: o Estado). Contudo o fazer intervém: um dos meios de possuir é transformar, trabalhar o material dado. $\mathrm{O}$ próprio agente, ao mesmo tempo, se transforma a si mesmo. Experimenta abstratamente sua liberdade como capacidade de transformação. Fazendo, faz-se (CHÂTELET, 1995, p. 126, grifo do autor).

Nessa perspectiva, pois, condenado ao desenvolvimento da atividade material, em virtude da sua condição humana, à medida que se inclina ao medo de perder a vida, ao escravo, se impõe um "comportamento animal", ao qual escapa em virtude da redescoberta da sua humanidade, sob o horizonte da relação dialética que envolve o caso em questão, diante da correspondência ativa que implica a sua ação no mundo das coisas, configurando, embora o mais baixo grau da realização da liberdade, posto que resulta apenas em um fenômeno abstrato, que não alcança um valor formador, à medida que se mantém reduzido à estagnação e à repetição, como o identifica Marx que, nas fronteiras da leitura hegeliana, pensa que

[...] O trabalho estranhado faz, por conseguinte:

3) do ser genérico do homem, tanto da natureza quanto da faculdade genérica espiritual dele, um ser estranho a ele, um meio da sua existência individual. Estranha do homem o seu próprio corpo, assim como a natureza fora dele, tal como a sua essência espiritual, a sua essência humana.

4) uma consequência imediata disto, de o homem estar estranhado do produto do seu trabalho, de sua atividade vital e de seu ser genérico é o estranhamento do homem pelo [próprio] homem. Quando o homem está frente a si mesmo, defronta-se com ele, o outro homem. O que é produto da relação do homem com o seu trabalho, produto de seu trabalho e consigo mesmo, vale como relação do homem com outro homem, como o trabalho e o objeto do trabalho de outro homem (MARX, 2004, p. 85-86, grifos do autor).

Se o conceito de alienação (Entfremdung) ${ }^{34}$, segundo a perspectiva hegeliana, corresponde ao momento no qual o espírito "sai de si" e se manifesta na construção da cultura, cuja ruptura, que se impõe através do movimento de exteriorização (através do trabalho), é superada pela operação da consciência (consciente de si, pois, nesse estágio superior), a relevância desta, sob o horizonte do idealismo que a encerra, acarreta, em suma, a perda da "materialidade do trabalho", de acordo com Marx ${ }^{35}$.

\section{Aspectos Conclusivos}

[...] Se o Estado é o espírito objetivo, então, só como membro é que o indivíduo tem objetividade, verdade e moralidade. A associação como tal é o

\footnotetext{
34 'Existe, pois, uma mudança de perspectiva. Em Marx, a alienação não designa mais um 'algo' enigmático e misterioso, uma qualidade ou propriedade do ser humano que se perderia no caminho e que é mister recuperar. Na filosofia hegeliana, restam traços da teologia judia-cristã: a divindade original, a queda, o pecado. No pensamento marxista, trata-se daquilo que impede $a$ realização de possibilidades" (DUVIGNAUD, 1974, p. 15, grifo do autor).

${ }^{35}$ [...] Marx estuda a produção no sentido mais amplo, muito mais vasto e profundo que no sentido econômico desse termo. O 'homem', ser social, produz obras e coisas; produz também relações sociais cada vez mais complexas. Nessa atividade, o homem real (social) não luta somente contra a natureza; é também a presa de suas próprias criaturas. Não somente, como havia suposto Feuerbach, da religião e da filosofia abstrata, mas do dinheiro e de suas consequências, das instituições, do próprio Estado. Necessidades históricas, inevitáveis mas logo superadas, se voltam contra o ser social e o oprimem. Quando há alienação? Quando há fetichismo e uma criação humana oprime o ser social do homem, fascinando-o. A alienação mais profunda é a alienação religiosa, que arranca completamente o ser humano de si mesmo. Mas a alienação essencial, na sociedade contemporânea, é a do trabalho e do trabalhador, vendendo este seu tempo de trabalho ao capitalista, isto é, seu tempo de atividade criadora e de vida social (DUVIGNAUD, 1974, p. 15, grifo do autor).
} 
verdadeiro conteúdo e o verdadeiro fim, e o destino dos indivíduos está em participarem numa vida coletiva; quaisquer outras satisfações, atividades e modalidades de comportamento têm o seu ponto de partida e o seu resultado neste ato substancial e universal. Considerada abstratamente, a racionalidade consiste essencialmente na íntima unidade do universal e do indivíduo e, quanto ao conteúdo no caso concreto de que aqui se trata, na unidade entre a liberdade objetiva, isto é, entre a vontade substancial e a liberdade objetiva como consciência individual, e a vontade que procura realizar os seus fins particulares; quanto à forma, constitui ela, por conseguinte, um comportamento que se determina segundo as leis e os princípios pensados, isto é, universais. Esta ideia é o ser universal e necessário em si e para si do espírito (HEGEL, 1997, p. 217-218).

Se, na circunscrição do movimento dialético, escapando ao horizonte da anterioridade e da exterioridade em relação ao Estado, a existência e o desenvolvimento da família e da sociedade civil somente se impõem em seu âmbito, esta última (a sociedade civil, no caso) corresponde à esfera intermediária (entre a família e o Estado), que, à medida que emerge como o arcabouço das atividades econômicas, converge para as fronteiras dos interesses privados que, carregando desde sempre entre si forças antagônicas, expõe, porque engendram, diferencialidades sócioeconômicas, entre outros vetores que não acenam senão para a construção de um nicho de combates, um teatro de rivalidades que tende a ameaçar a coletividade, tornando-se imprescindível a sujeição a uma ordem superior (a saber, a soberania do Estado), posto que o seu reconhecimento possibilita ao indivíduo a consciência de agir em busca do bem coletivo. Constituir a soberania a afirmação do caráter ideal de
toda a legitimidade particular não significa, ao contrário
do que muitas vezes se julga, que se possa considerá-
la como uma força absoluta, uma vazia arbitrariedade,
e confundi-la assim com o despotismo. Caracteriza o
despotismo, aquela ausência de lei em que a vontade
particular enquanto tal seja a de um monarca, seja a

de um povo, vale como lei ou, antes, vale em lugar da lei. Pelo contrário, no Estado constitucional legal, a soberania representa o que há de ideal nos domínios e atividades particulares; isso significa que tal domínio não é algo de autônomo e independente nos seus fins e modalidades, de fechado em si mesmo, pois nos seus fins e modalidades é definido pelos fins do conjunto (que em geral são designados, numa expressão vaga, por bem do Estado) (HEGEL, 1997, p. 253-254).

Se o homo oeconomicus carrega como motivação efetiva o interesse, a sociedade civil se impõe como o sistema que, caracterizado fundamentalmente pela instabilidade, estabelece a inter-relação que envolve as necessidades egoístas, interseccionando livremente a sua satisfação, possibilitando a expressão da força criadora do homem em sua individualidade, guardando, à sua atividade, imbricação com os demais com os quais se corresponde em um processo no qual a nenhuma ação se permite a condição de exterioridade, tendo em vista que "todo trabalho 'privado' é um trabalho 'público"', segundo a ênfase da leitura de Adam Smith $^{36}$, que identifica a "harmonia 'exterior"' que emerge através daqueles que, "produzindo", buscando cada um o seu interesse pessoal, em suma, concorrem para o bem geral, não se inclinando o indivíduo, sob tal perspectivação, senão a ser o que faz.

Como os indivíduos da coletividade são seres espirituais que, por isso, contêm os dois elementos de individualidade extrema consciente e voluntária e de universalidade extrema que conhece e quer a realidade substancial, como, portanto, tais indivíduos só conseguem justificar esses dois aspectos, quando agem como pessoas privadas e, ao mesmo tempo, como pessoas substanciais - nas esferas indicadas, alcançam, por outro lado, a primeira realidade imediatamente e, por outro lado, a segunda através de dois meios: nas instituições que são o que há de virtualmente universal, nos seus interesses particulares, têm, eles, a essência da sua consciência de si, e essas instituições lhes dão a seguir, nas corporações, uma atividade e uma ocupação dirigidas para um fim universal (HEGEL, 1997, p. 229).

\footnotetext{
36 "Segundo Adam Smith, existe uma ordem harmoniosa e benéfica das coisas, que se manifesta sempre que a natureza fica entregue a si mesma. As instituições humanas muitas vezes alteraram ou perturbaram a ordem natural, mas esta ainda pode ser encontrada sob as superestruturas históricas que a ocultam. Deve ser tarefa da ciência descobrir as leis determinantes dessa ordem e prescrever os meios pelos quais ela pode ser integralmente realizada nas sociedades humanas. Abolidos os sistemas de proteção ou de restrição, 'o sistema simples e fácil da liberdade natural instaura-se por si mesmo'. A única regra que esse sistema comporta é a liberdade ilimitada dos sujeitos econômicos. De fato, em virtude dessa liberdade, permite-se a ação da força natural própria da natureza humana, que, com sua ação constante em todos os homens, garante a realização da ordem econômica: a tendência egoísta." (ABBAGNANO, 2007, p. 300, grifo do autor).
} 
Nessa contextualidade, pois, o princípio do interesse - a cujo horizonte o indivíduo, "atomizado", não escapa -, se impõe para constituir um arcabouço no qual cada um torna-se adversário dos outros, emergindo inevitavelmente o conflito, no âmbito de cada atividade produtiva, tanto quanto entre as profissões, em face da concorrência, convergindo a sociedade para as fronteiras da oposição das classes ${ }^{37}$, tendo em vista que

Os meios infinitamente variados, bem como o movimento que os determina reciprocamente pela produção e pela troca, conduzem, por causa da universalidade imanente que possuem, a uma conjugação e a uma diferenciação em grupos gerais. Este todo adquire, então, a figura de um organismo formado por sistemas particulares de carências, técnicas e trabalhos, modos de satisfazer as carências, cultura teórica e prática, sistemas entre os quais se repartem os indivíduos, assim se estabelecendo as diferenças de classes (HEGEL, 1997, p. 180).

A divisão do trabalho, pois, que se impõe a qualquer atividade laboriosa, que demanda, em suma, uma distribuição dos encargos que encerram simultaneamente a ordem e a desordem, o sistema e a contradição, a igualdade formal e o antagonismo real, converge para a definição da condição de uma organização social que, sob a acepção de "campo de batalha dos interesses individuais de todos contra todos", a saber, a sociedade civil, segundo a concepção hegeliana (HEGEL, 1997, p. 267), não acena senão para a perspectiva que envolve um "sistema" que, trazendo como base os interesses individuais, propõe o êxito para cada um enquanto destina todos a um conflito mortal.
O império do direito privado só ilusoriamente é o da liberdade. A partir daí, esta reflui para si, compreende que tem de ser ela mesma seu próprio fundamento e que erraria em buscar fora de si o princípio de sua legitimação. À exteriorização na propriedade, no 'ter', se opõe logicamente a interiorização moralista. Esta é a negação abstrata daquela: doravante, é em si mesmo, como subjetividade, que o sujeito se constituirá como ser livre. No entanto, é bastante claro que a empíria desmente essa exigência. $O$ 'sujeito' de que se trata aqui não é o lugar mesmo onde se exercem as determinações as mais confusas e contraditórias? [...] É preciso, apesar da empíria, que o sujeito seja livre (senão, não é mais sujeito): deve sê-lo [...] (CHÂTELET, 1995, p. 128-129, grifo do autor).

A possibilidade de querer. Eis o significado para cujas fronteiras converge, nessa perspectiva, a leitura que implica a liberdade humana, tendo em vista que o seu próprio desejo, que emerge como que sujeito às forças da determinação animal, "se constitui, enquanto tal, como desejo humano", tornando desnecessária qualquer demonstração nesse sentido, segundo Hegel, cujo pensamento, transpondo o âmbito dos debates envolvendo o "livre-arbítrio"38 individual, dialoga com um horizonte que assinala que "o homem não é um animal", à medida que a distinção do homem, no que tange ao animal, não se impõe senão como humana, e não como animal . Conclusão: “[...] A partir do momento em que o conteúdo, o objeto e o fim do querer passam a ser ele mesmo, o universal, como forma infinita, o querer deixa de ser apenas a vontade livre em si, para ser também a vontade livre para si: é a Ideia em sua verdade" (HEGEL, 1997 , p. 25).

${ }^{37}$ A saber, "aquelas às quais a contingência histórica deu a posse dos meios de subsistência e aquelas que, na privação, são apenas o que fabricam" (CHÂTELET, 1995, p. 131, grifo nosso).

${ }^{38}$ A representação mais vulgar que se faz da liberdade é a do livre-arbítrio, meio-termo que a reflexão introduz entre a vontade simplesmente determinada pelos instintos naturais e a vontade livre em si e para si. Quando ouvimos dizer, de um modo absoluto, que a vontade consiste em poder fazer o que se queira, podemos considerar tal concepção como uma total falta de cultura do espírito, nela não se vê a mínima concepção do que sejam a vontade livre em si e para si, o direito, a moralidade, etc. A reflexão, generalidade e unidade formais da consciência de si, é a certeza abstrata que a vontade tem da sua liberdade, mas essa não é ainda a verdade, pois ela ainda não se tem a si mesma como fim e como conteúdo e o aspecto subjetivo ainda é diferente do aspecto material. O conteúdo desta determinação ainda está, por conseguinte, simplesmente limitado; longe de construir a vontade em sua verdade, o livre-arbítrio é antes a vontade enquanto contradição (HEGEL, 1997, p. 22-23).

39 “Tem, o animal, um círculo limitado de meios e modalidades para satisfazer as suas carências também limitadas, mas o homem, até no que tem dessa dependência animal, manifesta o poder de lhe escapar, e bem assim a sua universalidade, primeiro pela multiplicação das carências e dos meios, depois pela divisão e distinção das carências concretas em particularizadas, portanto, mais abstratas" (HEGEL, 1997, p. 174). 


\section{Referências}

ABBAGNANO, N. Dicionário de filosofia. São Paulo: Martins Fontes, 2007.

BARAQUIN, N.; LAFFITTE, J. Dicionário de filósofos. Lisboa: Edições 70, 2004. (Coleção Lexis).

CHÂTELET, F. Hegel. Rio de Janeiro: Jorge Zahar, 1995.

DUVIGNAUD, J. A sociologia: guia alfabético. Rio de Janeiro: Forense-Universitária, 1974.

HEGEL, G. W. F. A fenomenologia do espírito: parte 1. 2. ed. Petrópolis (RJ): Vozes, 1992.

. Ciencia de la logica. 6. ed. Buenos Aires:

Librarie Hachette, 1993.

- Enciclopédia das ciências filosóficas: a

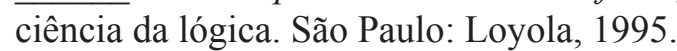

. Os pensadores. 2. ed. São Paulo: Abril Cultural, 1980.

- Princípios da filosofia do direito. São Paulo: Martins Fontes, 1997.

HYPPOLITE, J. Introdução à história da filosofia de Hegel. Rio de Janeiro: Civilização Brasileira, 1971.

JAPIASSÚ, H.; MARCONDES, D. Dicionário básico de filosofia. 5. ed. Rio de Janeiro: Zahar, 2008.

MARX, K. Manuscritos econômico-filosóficos. São Paulo: Boitempo, 2004.

MERQUIOR, J. G. Arte e sociedade em Marcuse, Adorno e Benjamin: ensaio crítico sobre a escola neohegeliana de Frankfurt. Rio de Janeiro: Tempo Brasileiro, 1969.

MORENTE, M. G. Fundamentos de filosofia: lições preliminares. 3. ed. São Paulo: Mestre Jou, 1967.

OLIVEIRA, M.A. Hegel, síntese entre racionalidade moderna e antiga? In: CHAGAS, E. F.; UTZ, K.; OLIVEIRA, J. W. J. (Org.). Comemoração aos 200 anos da "fenomenologia do espírito" de Hegel. Fortaleza: Edições UFC, 2007. p. 39-63.

ROSENFIELD, D. L. Politica e liberdade em Hegel. São Paulo: Brasiliense, 1983. 
Rosa, L. C. M. 